BENM 2021

International Scientific and Practical Conference "Biotechnology, Ecology, Nature Management"

\title{
INCREASING THE NUTRITIONAL VALUE OF ARTEMIA SALINA NAUPLII BY ENRICHING HAEMATOCOCCUS PLUVIALIS
}

\author{
A. K. Ponomarev (a)*, L. L. Brezhnev (b), A. V. Cherenkov (c) \\ *Corresponding author
}

(a) K.G. Razumovsky Moscow State University of Technologies and Management (the First Cossack University), 73, Zemlyanoy Val str., Moscow, Russia, ponomarev777@mail.ru

(b) K.G. Razumovsky Moscow State University of Technologies and Management (the First Cossack University), 73, Zemlyanoy Val str., Moscow, Russia,

(c) K.G. Razumovsky Moscow State University of Technologies and Management (the First Cossack University), 73, Zemlyanoy Val str., Moscow, Russia

\begin{abstract}
This article presents materials on the results of an experiment on the enrichment of Artemia salina with the unicellular alga Haematococcus pluvialis to increase its nutritional value. For fry of marine fish, such as mullet and kalkana, and freshwater fish, such as clary catfish, carp and trout, the supply of fatty acids and the energy value of Artemia is still insufficient. Therefore, it is necessary to enrich brine shrimp with additional nutrients The use of Haematococcus pluvialis as a component of salmon food allows an increase in the intensity of the red color of the muscle tissue. Research has shown that using Haematococcus pluvialis as a starter feed supplement can provide an additional source of protein and fat for fish fry. Experiments have shown that A. Salina, enriched with hematococus, increased the increase in size of zebrafish by $17.27 \%$ for 10 days of feeding in comparison with feeding with pure brine shrimp, which shows the effectiveness of using H. Pluvialis as a feed additive in the starter feed of fish fry and increased overall survival in the experimental group by $20 \%$.
\end{abstract}

2672-8575 ㄷ 2022 Published by European Publisher.

Keywords: Artemia salina, enriched brine shrimp, Haematococcus pluvialis, nauplii, starter feed 


\section{Introduction}

Live food is an essential component of the starter diet of many fish species. Most often, Artemia salina is used for these purposes, since it has a high energy value and is easily cultivated during the day (Spiller \& Dewell, 2003).

The nutritional value of brine shrimp can be increased by adding fatty acids, which are found in fish oil, as well as krill meal, vegetable oils and green algae (Olsen, 2000; Ponomarev, 2003).

The exit of crustaceans from the chorion is observed in the first hours after entering the water. Over time, the caloric content of the crustacean decreases, since the internal reserves are spent on its growth, and a day after hatching, the nutritional value of Artemia Salina decreases by more than 2 times (Chepurkina et al., 2014).

For fry of marine fish, such as mullet and kalkana, and freshwater fish, such as clary catfish, carp and trout, the supply of fatty acids and the energy value of Artemia is still insufficient. Therefore, it is necessary to enrich brine shrimp with additional nutrients (Guiry \& Guiry, 2020; Merchie, 1996).

Haematococcus pluvialis (Figure 1) is a species of freshwater green algae from the Haematococcaceae family, of the order Chlamydomonadaceae (Li et al., 2011). It is known for its high content of the strong antioxidant astaxanthin, which is used as a food additive in aquaculture, and is also used as a dietary supplement and a component of cosmetics (Shah et al., 2016).

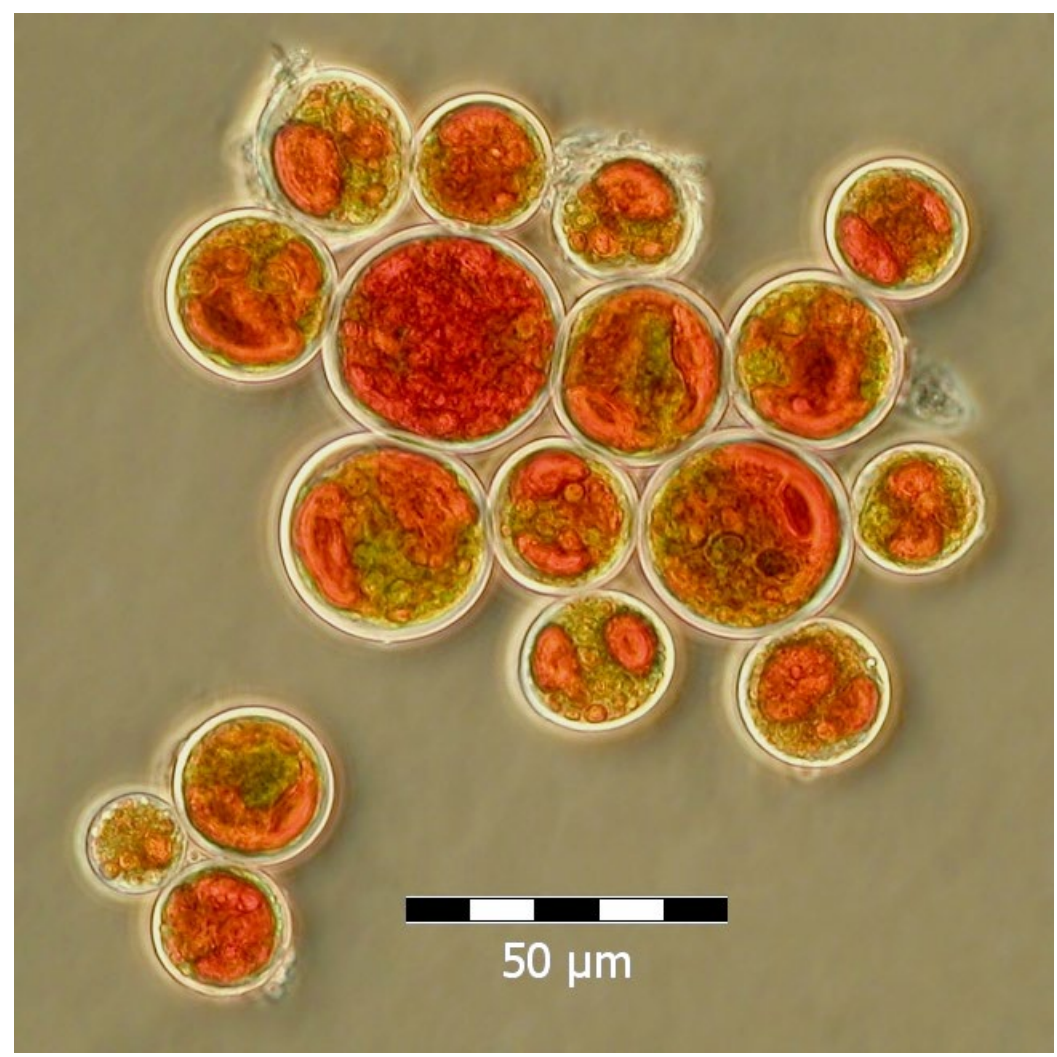

Figure 1. Haematococcus pluvalis 
The use of Haematococcus pluvialis as a component of food for salmonids makes it possible to achieve an increase in the intensity of the red color of muscle tissue, in particular, this alga is widely used in aquaculture in Southeast Asia, and its use is also allowed in the USA (with a restriction on the content of astaxanthin in the finished product). feed no more than $80 \mathrm{mg} / \mathrm{kg}$ (Gupta et al., 2007).

In good conditions, the alga is green in color, but if environmental conditions become unfavorable for normal cell growth (in particular, under the action of bright light, high salinity and low availability of nutrients), the cells enter the dormant phase and intensively produce and accumulate astaxanthin. becoming red (Gupta et al., 2007).

Haematococcus pluvialis is rich in proteins and consists of $29-45 \%$ of them. The amino acid composition is mainly represented by aspartic acid, glutamic acid, alanine and leucine with a total acid content of 10.02 / $100 \mathrm{mg} .46 \%$ of these amino acids are essential. Carbohydrates make up $15-17 \%$ of the composition. Lipids make up 20-25\%, about $10 \%$ of which are short polyunsaturated fatty acids. The predominant ones are neutral lipids. A more detailed composition of the algae is presented in Table 2.

The above information suggests that using Haematococcus pluvialis as a starter feed supplement could provide an additional source of protein and fat for fish fry.

The studies were carried out on the basis of the Russian-Scandinavian Center for Research and Innovation in the Field of Aquaculture, Moscow State University of Technologies and Management named K.G. Razumovsky (PKU).

\section{Purpose of the Study}

Study of the effect of Haematococcus pluvialis enriched with A. salina on survival and morphometric parameters of Danio rerio juveniles.

\section{Research Methods}

Cultivation of Haematococcus pluvialis (strain IBCE-17) was carried out on modified Rudik's medium at 14 hours of light - 10 hours of darkness and at a temperature of $28 \pm 2^{\circ} \mathrm{C}$, the density of the algae ready for use was 65 individuals / $\mathrm{ml}$. The composition of Rudik's medium is shown in Table 1.

Table 1. Composition of Rudik's environment

\begin{tabular}{cc|cc}
\hline \multicolumn{2}{c|}{ Macronutrients, g / } & \multicolumn{2}{c}{ Trace elements, $\mathrm{mg} / 1$} \\
\hline $\mathrm{NaNO} 3$ & 0,3 & $\mathrm{H} 3 \mathrm{BO} 3$ & 0,3 \\
$\mathrm{~K} 2 \mathrm{HPO}$ & 0,08 & $\mathrm{MnSO} 4 \cdot \mathrm{H} 2 \mathrm{O}$ & 1,5 \\
$\mathrm{KH} 2 \mathrm{PO} 4$ & 0,02 & $\mathrm{ZnSO} 4 \cdot 7 \mathrm{H} 2 \mathrm{O}$ & 0,1 \\
$\mathrm{MgSO} 4 \cdot 7 \mathrm{H} 2 \mathrm{O}$ & 0,01 & $\mathrm{NH} 4) 6 \mathrm{Mo} 7 \mathrm{O} 24 \cdot 9 \mathrm{H} 2 \mathrm{O}$ & 0,3 \\
$\mathrm{CaCl} 2 \cdot 2 \mathrm{H} 2 \mathrm{O}$ & 0,0585 & $\mathrm{CuSO} 4 \cdot 5 \mathrm{H} 2 \mathrm{O}$ & 0,08 \\
$\mathrm{EDTA}$ & 0,0075 & $\mathrm{Co}(\mathrm{NO} 3) 2 \cdot 6 \mathrm{H} 2 \mathrm{O}$ & 0,26 \\
$\mathrm{NaCl}$ & 0,02 & $\mathrm{FeCl} 3 \cdot 6 \mathrm{H} 2 \mathrm{O}$ & 17 \\
& & & \\
\hline
\end{tabular}

The incubation of A. salina was carried out in a $3 \% \mathrm{NaCl}$ solution in a cultivator at a temperature

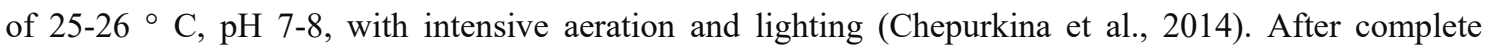


hatching of the nauplii, hematococcus was added to the reservoir with brine shrimp in a 1: 1 ratio and the brine shrimp was enriched within 2 hours. Feeding experiments were carried out on $\sim 0.4 \mathrm{~mm}$ Danio rerio larvae. After that, they were fed according to their consumption - 6 times a day for 10 days. The control group was fed with unenriched brine shrimp bred under the same parameters.

The filling of the digestive tract of A. Salina nauplii with hematococcus took 1 to 2 hours, depending on the density of A. Salina in solution (Miyamoto et al., 1985).

The morphology of A. Salina nauplis was examined for abnormalities using microscopy.

For the experiment, 60 Danio rerio juveniles were selected from which 2 groups were selected: control and experimental, 30 individuals in each. The average size of a Danio Rerio specimen at the beginning of the experiment was $0.4 \mathrm{~mm}$.

Measurements of the size of each individual were carried out at the beginning and at the end of the experiment, and on the basis of the data obtained, the average size of Danio Rerio individuals was obtained, as well as the increase in percentage.

\section{Findings}

Over the observation period, the average increase in the experimental group at the end of the experiment was $62.9 \%$, while in the control group it was $45.63 \%$. Artemia, enriched with Haematococcus pluvialis, increased the increase by $17.27 \%$ over the observed period in relation to the control group.

On the 3-4th day of the experiment, the experimental group greatly increased in size, and the difference was $8.4 \%$. At the end of the first week of the experiment, the difference in size between the groups was $15.5 \%$ or 1.146 times. From day 7 until the end of observations, the average percentage difference between the experimental groups was $16.8 \%$.

The survival rate was also recorded, at the end of the experiment the difference was $20 \%$ percent, in the experimental group there was zero mortality.

\section{Conclusion}

The results obtained show the effectiveness of the developed method to increase the nutritional value of Artemia due to the fact that in the process of feeding Artemia, H.pluvialis enters the red phase the protective function of the microalgae cell, during which its nutritional composition greatly changes, Table 2 shows the composition of the hematococcus in comparison green (normal) and red (protective) phase of the cell.

Table 2. Composition of H. Pluvialis in the "green" and "red" stages "

\begin{tabular}{ccc}
\hline Composition, \% & Green stage & Red stage \\
\hline Proteins (total \%) & $29-45$ & $17-25$ \\
Lipids (total \%) & $20-25$ & $32-27$ \\
• Neutral lipids & 59 & $51,9-53,5$ \\
• Phospholipids & 23,7 & $20,6-21,1$ \\
$\bullet$ Glycolipids & 11,5 & $25,7-26,5$ \\
Carbohydrates (total\%) & $15-17$ & $36-40$
\end{tabular}


Selection and peer-review under responsibility of the Organizing Committee of the conference eISSN: $2672-8575$

$\begin{array}{ccr}\text { Carotenoids (total\%) } & 0,5 & 2-5 \\ \bullet \text { Neoxanthin } & 8,3 & \text { n.d } \\ \bullet \text { Violaxanthin } & 12.5 & \text { n.d } \\ \text { • } \beta \text {-carotene } & 16,7 & 1,0 \\ \text { • Lutein } & 56,3 & 0,5 \\ \text { • Zeaxanthin } & 6,3 & \text { n.d } \\ \text { Astaxanthin (including esters) } & \text { n.d } & 81,2 \\ \text { • Adonixanthin } & \text { n.d } & 0,4 \\ \text { • Adonirubin } & \text { n.d } & 0,6 \\ \text { • Canthaxanthin } & \text { n.d } & 5,1 \\ \text { • Echinenon } & \text { n.d } & 0,2 \\ \text { • Chlorophyll } & 1,5-2 & 0\end{array}$

From the presented table, one can draw attention to a sharp increase in free lipids by $60 \%$ by $122 \%$ of glycolepids, and by almost 140\% increase in carbohydrates. On the photomicrographs (Figure 2 B), one can pay attention to the presence of algae in the red stage. Figure 2 (A) demonstrates the complete filling of the intestine of A salina with a culture of microalgae.

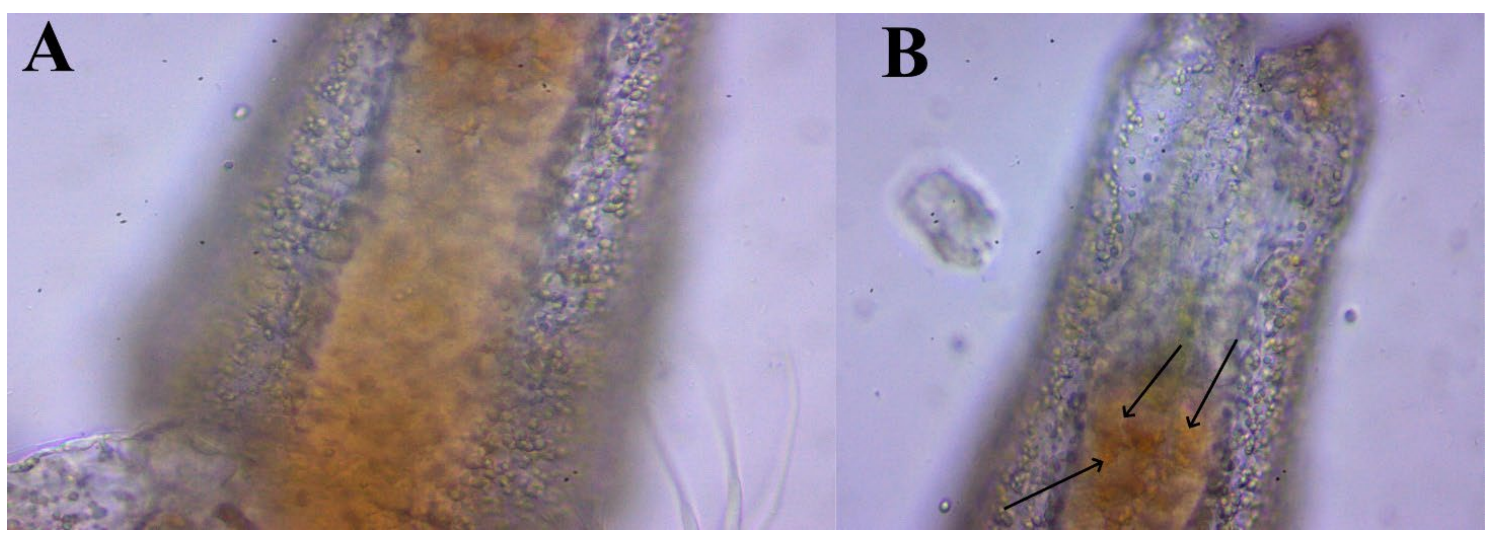

Figure 2. Artemia enriched with the culture of H. Pluvialis, in image B the arrows show the transition of the microalga to the red phase

A. Salina, enriched with hematococus, increased the increase in size of zebrafish by $17.27 \%$ for 10 days of feeding in comparison with feeding with pure brine shrimp, which shows the effectiveness of using H. Pluvialis as a feed additive in the starter feed of fish fry.

\section{References}

Chepurkina, M. A., Gileva, E. A., Prusinska, M., \& Kolman, R. (2014). Using the method of enrichment of brine shrimp nauplii in sturgeon breeding. Bulletin of Fisheries Science, 4(4), 78-90.

Guiry, M. D., \& Guiry, G. M. (2020). AlgaeBase. World-wide electronic publication, National University of Ireland, Galway.

Gupta, S. K., Jha, A. K., Pal, A. K., \& Venkateshwarlu, G. (2007). Use of natural carotenoids for pigmentation in fishes. CSIR.

Li, J., Zhu, D., Niu, J., Shen, S., \& Wang, G. (2011). An economic assessment of astaxanthin production by large scale cultivation of Haematococcus pluvialis. Biotechnology Advances, 29(6), 568-574. https://doi.org/10.1016/j.biotechadv.2011.04.001 
Merchie, G. (1996). Use of nauplii and meta-nauplii. In P. Lavens, P. Sorgeloos (Eds.), Manual on the production and use of live foot for aquaculture. University of Ghent.

Miyamoto, G., Landau, M., \& Bolis, C. (1985). Growth and Amino Acid Composition of Artemia Salina (L., 1758) Fed Algae Grown in Different Media (Anostraca). Crustaceana, 49(1-3), 318-321. https://doi.org/10.1163/156854085X00657

Olsen, A. I. (2000). Effects of short term feeding of microalgae on the bacterial flora associated with juvenile Artemia franciscana. In A. I. Olsen, \& Y. Olsen (Eds.), Attramadal. Aquaculture, 11-25. https://doi.org/10.1016/S0044-8486(00)00396-3

Ponomarev, A. K. (2003). Histological and histochemical analysis of gametogenesis and the state of hepatopancreas. In Procambarus Clarkii with different feeding options. Moscow State Technological Academy.

Shah, M. M. R., Liang, Y., Cheng, J. J., \& Daroch, M. (2016). Astaxanthin-Producing Green Microalga Haematococcus pluvialis: From Single Cell to High Value Commercial Products. Frontiers in Plant Science, 7. https://doi.org/10.3389/fpls.2016.00531

Spiller, G. A., \& Dewell, A. (2003). Safety of an Astaxanthin-Rich Haematococcus pluvialis Algal Extract: A Randomized Clinical Trial. Journal of Medicinal Food, 3(6), 51-56. https://doi.org/10.1089/109662003765184741 